PRZEGLĄD RUSYCYSTYCZNY 2020, nr 2(170)

DOI $10.31261 /$ pr. 7767

\author{
LILIANA KALITA
}

Uniwersytet Gdański

(D) ORCID: http://orcid.org/oooo-0oo2-6025-2643

\title{
MARYNARKA OD BURBERRY CZY KURTKA PUCHOWA? UBRANIE A EWOLUCJA BOHATERA POWIEŚCI ANDRIEJA GIEŁASIMOWA ХОЛОД
}

W kulturze współczesnej rzeczy podlegają wzmożonej semiozie, stają się znakami. Gwałtowna 'przemijalność' rzeczy, które odchodzą (jak samochód syrena) albo przychodzą (jak telefon komórkowy) w sposób 'epidemiczny' nadaje dynamiki współczesnemu dyskursowi kulturowemu. Za życia jednego pokolenia zmienia się co najmniej dwukrotnie świat przedmiotowy w wybranych dziedzinach (samochody, meble, telewizory, telefony)

- pisze w Antropologii codzienności Roch Sulima1. Znaczenie otaczających nas przedmiotów codziennego użytku, ich rolę w konstytuowaniu tożsamości człowieka i jego miejsca w świecie podkreśla również Joanna Szydłowska, zdaniem której

za ich przyczyną realizuje się ludzka praktyka działań społecznych, zachowań ekonomicznych, aktów psychiczno-behawioralnych oraz praktyka pamięci. Rzeczy jako elementy kultury materialnej, mogą być percypowane w wielu aspektach np.: funkcjonalnym, symbolicznym, prestiżowym, społecznym, estetycznym, religijnym ${ }^{2}$.

Rosyjski badacz „historii w zwierciadle życia codziennego” - Jurij Łotman - przekonuje, że „w s z y s t k i e otaczające nas rzeczy

1 R. Sulima, Antropologia codzienności, Wydawnictwo Uniwersytetu Jagiellońskiego, Kraków 2000, s. 9.

2 J. Szydłowska, Retoryka rzeczy a proces zadomowienia $w$ przestrzeniach pojattańskiego Okcydentu, http://www.anthropos.us.edu.pl/anthropos9/texty/szydlowska.htm (28.02.2019). 
są nie tylko elementem praksis w ogóle, ale również częścią praktyki społecznej, stają się jak gdyby kwintesencją relacji pomiędzy ludźmi i w tej funkcji mogą nabierać symbolicznego charakteru"3. Do przedmiotów, które towarzyszą naszej codzienności, oprócz wskazanych powyżej, zaliczyć możemy również ubranie, zwane powszechnie „drugą skórą", które nie tylko wyraża osobowość tego, kto je nosi, ale jest często, zwłaszcza w ekstremalnych warunkach klimatycznych, gwarancją zachowania zdrowia, a nawet przeżycia. Cenne uwagi na temat znaczenia i funkcji kostiumu w literaturze znajdziemy w klasycznym już opracowaniu Jerzego Faryno ${ }^{4}$, w którym podkreślona zostaje m.in. rola ubioru w modelowaniu koncepcji postaci czy czasowo-przestrzennych kategorii utworu.

Problematyka codzienności jest od lat obecna w refleksji historyków literatury rosyjskiej ${ }^{5}$, zresztą pisarze zza wschodniej granicy systematycznie dostarczają badaczom nowego materiału, by wymienić chociażby takich autorów, jak Dmitrij Daniłow, Oleg Pawłow, Aleksandr Iliczewskij czy Andriej Giełasimow. Znaczenie kodu odzieżowego w literaturze rosyjskiej znaczące jest zarówno w gatunkach typowych dla folkloru, na przykład w bajce, jak i w utworach pisarzy epok późniejszych, m.in. Denisa Fonwizina, Aleksandra Puszkina czy Nikołaja Gogola ${ }^{6}$. Wśród tekstów najnowszej literatury rosyjskiej penetrujących obszary codzienności również można odnotować obecność motywu ubrania, wykorzystywanego przez pisarzy odmiennych często stylistyk i pełniącego różne funkcje w tekście. Warto tu

3 J. Łotman, Rosja i znaki. Kultura szlachecka $w$ wieku XVIII i na początku XIX, przekład i posłowie B. Żyłko, Wydawnictwo słowo/obraz terytoria, Gdańsk 2010, s. 11.

4 Zob. Е. Фарино, Введение в литературоведение, Изд. РГПУ им. А. И. Герцена, Санкт-Петербург 2004, с. 183-197.

5 Zob. np.: A. Skotnicka, Niezwykłość codzienności w rosyjskiej prozie drugiej potowy XX wieku, w: I. Malej, Z. Tarajło-Lipowska (red.), Wielkie tematy kultury $w$ literaturach słowiańskich, t. 6, Wydawnictwo Uniwersytetu Wrocławskiego, Wrocław 2004, s. 135-141; W. Supa (red.), W kręgu problemów antropologii literatury. Antropologia codzienności, Wydawnictwo Uniwersytetu w Białymstoku, Białystok 2013; P. Charko-Klekot, Szaleństwo codzienności we współczesnej dramaturgii rosyjskiej, „Zeszyty Naukowe Towarzystwa Doktorantów UJ. Nauki Humanistyczne" 2017, nr 8, s. 81-97, https://www.depot.ceon.pl/bitstream/ handle/123456789/14136/06.\%20Charko-Klekot\%20Szale\%C5\%84stwo\%20codzienno\%C5\%9Bci\%20we\%20wsp\%C3\%B3\%C5\%82czesnej\%2odramaturgii\%20 rosyjskiej.pdf? sequence $=1 \&$ isAllowed $=y(28.02 .2019)$.

6 Zob. О. Г. Лазареску, Предметный мотив одежды в русской литературе и фольклоре, https://cyberleninka.ru/article/n/predmetnyy-motiv-odezhdy-vrusskoy-literature-i-folklore (28.02.2019). 
przywołać chociażby takie utwory prozatorskie, jak Рубашка (2004) Jewgienija Griszkowca czy cykl Borysa Akunina o Eraście Fandorinie (1998-2018). W powieści Griszkowca tytułowa koszula symbolizuje status bohatera oraz jest jednym z wcieleń „drugiego Ja” protagonisty $^{7}$, natomiast ekscentryczna ekstrawagancja Fandorina eksponuje indywidualność postaci, jak również jest polemiką ze stereotypem Rosjanina oraz zaprzeczeniem socrealistycznej uniformizacji bohaterów literackich ${ }^{8}$.

Andriej Giełasimow (ur. 1965), germanista i reżyser teatralny, debiutował w 2001 roku opowieścią Фокс Малдер похож на свинъю. Utwór ten był nominowany do nagrody Iwana Biełkina, ale też znalazł się na liście pięćdziesięciu najlepszych prozatorskich debiutów początku trzeciego tysiąclecia9. Kolejny tekst pisarza - Жажда (2002), nagrodzony został przez miesięcznik „Oktiabr”, zaś powieść Рахиль (2003) zdobyła „Studenckiego Bookera”. Najbardziej docenionym tekstem Giełasimowa jest jednak powieść Степные боги (2008), która w 2009 roku otrzymała nagrodę „Nacionalnyj bestseller”. W 2015 roku Giełasimow opublikował powieść Холод, będącą przedmiotem rozważań w tym szkicu. Choć teksty Giełasimowa są nagradzane i cieszą się dużym zainteresowaniem czytelników, krytyka odnosi się do pisarza niejednoznacznie. Dmitrij Bykow ironiczny stosunek do autora Pragnienia zawarł w tytule swojego artykułu, samego Giełasimowa nazwał zaś „przyjemnym pisarzem, który nie pozostaje w głowie" ${ }^{10}$. Zdaniem Marii Remizowej natomiast, choć pisarz zakłada maskę „swojego chłopa” udaje mu się „organicznie wnikać w istotę $\mathrm{i}-\mathrm{w}$ konsekwencji - w psychologię wszystkich swoich bohaterów"11. Waleria Pustowaja docenia z kolei styl opowiadania Giełasi-

7 Zob. Ф. И. Ахмадишина, Проблема самоидентификации в романе Е. Гришковца „Рубашка”, w: Г. Д. Ахметова (red), Современная филология: материалы III Междунар. науч. конф. (г. Уфа, июнь 2014 г.), Лето, Уфа 2014, с. 4345, https://moluch.ru/conf/phil/archive/108/5793/ (28.02.2019).

8 Zob. E. Żak, Mieszkańcy rosyjskiej świadomości zbiorowej XX i XXI wieku. Bohater kryminałów Aleksandry Marininej i Borysa Akunina, Księgarnia Akademicka, Kraków 2014, s. 246-251.

9 Вяч. Калмыков, 5о самых ярких дебютов в прозе начала третьего тысячелетия, „Литературная Россия”, 25.03.2005, http://web.archive.org/web/ 20130920233835/http://litrossia.ru/archive/140/reit/3457.php (28.02.2019).

10 Д. Быков, Андрей Геласимов похож на писателя, „Новый мир” 2003, nr 1, http://www.zh-zal.ru/novyi_mi/2003/1/bykov.html (28.02.2019). Jeśli nie wskazuję tłumaczy, w całym artykule przekład mój - L. K.

${ }^{11}$ М. Ремизова, Здравствуй, проза молодая..., „Знамя” 2003, nr 12, http:// znamlit.ru/publication.php?id=2213 (28.02.2019). 
mowa i umiejętność utrzymania zainteresowania czytelnika przedstawianą historią, pisząc, że jest on „narratorem-wirtuozem umiejącym rozochocić, zadziwić i obiecać dopowiedzieć wszystko jutro" ${ }^{12}$. Sam Giełasimow zdaje się podchodzić z dystansem do zróżnicowanych opinii na temat swojej twórczości i po prostu wykorzystuje sprzyjającą mu koniunkturę, by wydawać i sprzedawać kolejne książki. Przedmiotem refleksji pisarza w utworze Холод jest kondycja współczesnego człowieka, którego losy splecione zostały ze skutkami przemian ustrojowych państwa, penetracja psychiki postaci, motywów jej działań i meandrów osobowości. Pisarz o koncepcji swojej postaci mówił tak: „W poprzednich utworach wszyscy moi bohaterowie byli sympatyczni: kochający, cierpiący, znajdujący się w sytuacji poszukiwania wyjścia z tego cierpienia. Tym razem stworzyłem bohatera, który nie cierpi. To chodzący trup"13. W kontekście tej wypowiedzi symbolicznej wymowy nabiera tytuł powieści, odnoszący się nie tylko do zamarzającego $\mathrm{w}$ wyniku katastrofy energetycznej miasta ${ }^{14}$ i jego mieszkańców, ale przede wszystkim do martwoty duchowej bohatera i próby odnalezienia przez niego utraconego sensu życia.

Główną postacią omawianego utworu jest 42-letni reżyser teatralny i filmowy Eduard Filippow, zwany Filą, znajdujący się obecnie u szczytu sławy, który po dziesięciu latach pracy w Europie Zachodniej przyjeżdża do rodzinnego miasta na północy Rosji. Podróż to jeden $\mathrm{z}$ najbardziej powszechnych wątków literackich, służący bohaterowi między innymi, i tak się dzieje w powieści Giełasimowa, do poznania samego siebie poprzez skonfrontowanie wewnętrznego „Ja” z obrazem wykreowanym na potrzeby otoczenia ${ }^{15}$. Powrót po latach nie jest dobrowolną decyzją reżysera - Filippow chce wyprosić u swojego kolegi scenografa szkice do kolejnego spektaklu. Wizyta ma trwać jeden dzień. Jednak nietypowa dla końca października ano-

${ }^{12}$ В. Пустовая, Добрый доктор Геласимов, „Новый мир” 2005, nr 2, https:// magazines.gorky.media/novyi_mi/2005/2/dobryj-doktor-gelasimov.html (28.02.2019).

${ }^{13}$ С. Прудников, Андрей Геласимов: Какой-то холод в нас вползает..., „Вечерний Петербург" 2015, nr 186, http://www.vppress.ru/stories/Andrei-Gelasimov-Kakoi-to-kholod-v-nas-vpolzaet-30568 (3.03.2019).

${ }^{14}$ Chociaż w utworze nie pada nazwa miejscowości, w której dzieje się akcja utworu, dość szybko zostało ono rozszyfrowane jako Jakuck, w którym faktycznie doszło w 2002 roku do awarii energetycznej. Por. О. Яковлева, О. Иванова, Концепт „город Якутск” в романе А. Геласимова „Холод”, https://interactive-plus.ru/e-articles/285/Action285-115185.pdf (3.03.2019).

${ }^{15}$ O motywie podróży zob. na przykład: D. Kozicka, Podróżny horyzont rozumienia, „Teksty Drugie” 2006, nr 1-2, s. 270-285. 
malia pogodowa - spadek temperatury poniżej 40 stopni Celsjusza oraz awaria miejskiej sieci energetycznej zatrzymują bohatera na dłużej i stają się powodem wydarzeń, które zmuszą go do przemyślenia dotychczasowych wyborów.

W utworze wyróżnić można dwie płaszczyzny czasowe - teraźniejszą, dziejącą się w 2007 roku, związaną z przeżyciami bohatera w sytuacji ekstremalnych warunków atmosferycznych, oraz tę sprzed dziesięciu lat, funkcjonującą na zasadzie retrospekcji we wspomnieniach lub wizjach Filippowa. Schemat fabularny utworu oparty jest na motywie drogi i immanentnie związanym z nią motywem spotkania, bohatera obserwujemy bowiem w jego licznych wędrówkach po mieście i relacjach ze znanymi z przeszłości lub nowo poznanymi ludźmi. Sytuacje, w jakich stawia Giełasimow Filippowa, wyznaczają szczególne etapy biografii bohatera, skłaniając go do refleksji nad własnym życiem i w efekcie nabierają cech ekspiacji za niewłaściwe postawy i decyzje sprzed lat.

Motto otwierające powieść Giełasimowa odsyła nas do motywu piekła utożsamianego z chłodem, co wydaje się aluzją do Boskiej komedii (Divina Commedia, 1308-1321) Dantego, a zatem konfrontację protagonisty z samym sobą w rodzinnym mieście, zakończoną ostatecznie jego śmiercią można traktować jako zstępowanie Filippowa do krainy śmierci (wymowna pod względem aksjologii jest oparta na malejącej gradacji trójdzielna kompozycja utworu, sygnalizowana rozdziałami o tytułach: Заморозки, Точка замерзания, Абсолютный ноль). Nawiązania do tekstu Dantego, traktowanego przecież jako metafora wędrówki przez piekło na ziemi, są zresztą u Giełasimowa liczniejsze - warto odnotować chociażby zbliżony wiek bohaterów obu utworów, obecność towarzysza podróży (u Dantego - Wergiliusz, u Giełasimowa - Demon Pustki), nawiązanie do piekielnego bestiarium poprzez wprowadzenie motywu psa czy wreszcie podział utworu na trzy częśsi ${ }^{16}$.

Transformacja postaci, dokonująca się w toku rozwoju akcji, przebiega na linii od egoisty (powody przyjazdu do miasta) do altruisty, ratującego życie młodego chłopaka, któremu oddaje swoją kurtkę, co jest jednoznaczne ze skazaniem samego siebie na śmierć. Przemiana, jaka następuje w bohaterze, stanowi oś konstrukcyjną postaci, a jednym z sygnałów procesów dokonujących się w psychice bohatera jest

${ }^{16}$ Intertekstualne nawiązania powieści Giełasimowa do utworu Dantego oraz innych tekstów kultury wymagają szczegółowych analiz i wykraczają poza problematykę niniejszego tekstu. 
ulegające zmianie ubranie Filippowa. Odzież pełni w utworze funkcję m.in. charakterystyki bohatera, przez pryzmat ubioru, stosunku postaci do mody poznajemy jego świat wewnętrzny i motywacje zachowań dawnych i obecnych, a także obserwujemy ewolucję, jaka się w nim dokonuje. Anthony Giddens, rozpatrując zjawiska charakterystyczne dla epoki nowoczesności, zwraca uwagę, że szczególnego znaczenia w tym czasie nabierają wizerunek i sposób bycia: „[...] wygląd zewnętrzny staje się głównym elementem refleksyjnego projektu ‘ja”, co sprawia, że „tożsamość jednostki rozpada się na szereg różnych sytuacyjnych tożsamości, którym brak wewnętrznej osi tożsamości „ja”17. W przypadku głównego bohatera powieści Giełasimowa, podobnie zresztą jak u Aleksandra z Koszuli Griszkowca, borykających się z rozterkami psychicznymi wynikającymi z zagubienia autentyczności własnej osoby, tożsamość i jej manifestacja poprzez strój są silnie powiązane z wizerunkiem człowieka sukcesu kreowanego przez media. Ubranie, biżuteria, przedmioty codziennego użytku tworzą symbole statusu, za pomocą których człowiek eksponuje przynależność do konkretnego otoczenia społecznego, przy czym, jak zauważa Krzysztof Pietrowicz - przez to ostatnie należy rozumieć nie grupy lokalne, lecz „grupy odniesienia kreowane przez media elektroniczne, przede wszystkim telewizję"18.

Tę strategię potwierdza sposób kreowania bohatera: Eduard Filippow jest zaprezentowany jako utalentowany reżyser-eksperymentator, którego przedstawienia cieszą się powodzeniem u widzów. Artysta uchodzi za postać „kultową” wśród miłośników teatru i zwykłych obywateli, bowiem jego życie zawodowe i prywatne jest tematem licznych artykułów prasowych. Odsłony na portalach społecznościowych związane z jego osobą liczone są w dziesiątkach tysięcy wejść. Bohater ma zatem podwójny status: produktu kultury masowej (znany z prasy celebryta) i twórcy kultury wysokiej (jako reżyser, wpisujący się w ponowoczesne tendencje realizacji widowisk z wykorzystaniem ekscentrycznych rekwizytów i szokujących rozwiązań scenicznych). Bycie „postacią z okładki” pomaga mu w zdobywaniu kolejnych intratnych kontraktów i powiększaniu stanu swego konta, co wydaje się głównym celem życia Filippowa. Zachowania bohatera, jego codzienne

${ }^{17}$ A. Giddens, Nowoczesność $i$ tożsamość. „Ja” i spoleczeństwo w epoce późnej nowoczesności, przeł. A. Szulżycka, PWN, Warszawa 2001, s. 137-138.

${ }^{18}$ K. Pietrowicz, Nasze gadżety codzienne, albo o płynności symboli statusu, w: T. Szlendak, K. Pietrowicz (red.), Na pokaz. O konsumeryzmie w kapitalizmie bez kapitału, Wydawnictwo Uniwersytetu Mikołaja Kopernika, Toruń 2004, s. 70. 
wybory dotyczące chociażby ubioru czy sposobu spędzania czasu wpisują się zarówno w lansowany w mediach styl życia konsumpcyjnego, jak też powszechne wyobrażenia o rozrywkach bohemy artystycznej, $\mathrm{z}$ takimi ich elementami jak nadmierne spożywanie alkoholu, wikłanie się w przelotne romanse, nieustanne szokowanie intymnymi zwierzeniami i epatowanie własną oryginalnością. Bohater swoją ekstrawagancją w wyglądzie i obejściu przypomina dandysa, łączącego „wielkoświatową modę, rozmyślną impertynencję i cynizm”" z czasem okaże się jednak, że taka postawa to maska, mająca skrywać prawdziwe - zagubione i targane wyrzutami sumienia - „ja” protagonisty. Już sam początek utworu przynosi informację, że Filippow żyje na pokaz: upija się markowym alkoholem, kupuje drogie i modne ubrania (metka z nazwą firmy na odzieży ma dla niego znaczenie). W sytuacjach życia codziennego, nawet tych kłopotliwych (pobudka na kacu), troszczy się przede wszystkim o pogniecioną garderobę:

- Не могла, что ли, пиджак снять?... Он, между прочим, от Burberry.

- Вы сами не дали. Сказали, что вам будет холодно ${ }^{20}$.

Zasygnalizowane $\mathrm{w}$ początkowych fragmentach powieści eksponujących postać Filippowa przywiązanie do markowej odzieży może być zarówno sposobem indywidualizacji bohatera, jak i sygnałem umiejscowienia go w przestrzeni socjalnej jako celebryty. Silne utożsamianie się bohatera z ubraniem sprawia, że marynarka od Burberry to maska, w jakiej chce pokazywać się światu, a jednocześnie pancerz, za którym bohater skrywa swoje prawdziwe ,ja”. Taką interpretację uprawomocnia ideowa koncepcja utworu, wykorzystująca napięcie pomiędzy prawdziwą tożsamością protagonisty a jego autoprezentacją. Kontrolowanie przez Filippowa swojego image'u, którego ważnym elementem jest wygląd zewnętrzny, osłanianie ciała pięknymi i kosztownymi tkaninami, może być odczytywane jako brak woli zmierzenia się z ignorowanymi przez lata problemami i prawdą na swój temat. Akcentowanie znaczenia, jakie w życiu bohatera odgrywa odzież - to wszak rodzaj opakowania - to sygnał odwrócenia uwagi od wnętrza czy też zawartości - duszy i emocji, które, jak pokaże fabuła utworu, wymagają naprawy. Innym sposobem na rozgrzanie ciągle marznącego ciała jest również alkohol, który w utworze

19 J. Łotman, Rosja i znaki..., s. 142.

${ }^{20}$ А. Геласимов, Холод: роман в трех действиях с антрактами, Москва 2015, s. 13. Dalej cytuję według tego wydania, wskazując w nawiasie numer strony. 
pełni różne funkcje - to trunek rozszerzający świadomość, budzący natchnienie; to także możliwość ucieczki przed rzeczywistością i jej wyzwaniami. Gdy pasażerowie samolotu, którym bohater zmierza do rodzinnego miasta, przygotowują się do lądowania, reżyser zauważa, że jego wygląd znacząco różni się od pozostałych. Niemal wszyscy mają na sobie grube kurtki, czapki, rękawice, usta zaś osłaniają szalem, podczas gdy on ubrany jest w płaszcz od Dirk Bikkembergs (pod którym znajduje się wspomniana marynarka) oraz trampki od Kris Van Assche. Jego strój, będący oznaką statusu materialnego i pozycji zawodowej, w momencie zbliżania się bohatera do rodzinnego miasta i tym samym oddalania od utożsamianego z dominacją kultury materialnej Zachodu staje się symbolem nieprzystawalności i obcości zarówno wobec rosyjskiej części własnej biografii, jak i kultury Rosji jako takiej. W rezultacie sam bohater jawi się jako śmieszny i żałosny jednocześnie, ale przede wszystkim obcy, którego obecność wywołuje rezerwę, niepokój, a nawet wrogość. Antagonizm pomiędzy reżyserem a mieszkańcami miasta ujawnia się różnorako: na poziomie relacji z innymi będzie przybierać postać traktowania Filippowa jako alkoholika, bezdomnego czy wreszcie pacjenta szpitala dla psychicznie chorych, z kolei na poziomie czasowo-przestrzennym świadectwem tego są chociażby negatywne wspomnienia Filippowa, przeskoki temporalne $\mathrm{w}$ narracji prowadzonej z jego punktu widzenia, wybiórcze prezentowanie zdarzeń oraz chaotyczne początkowo, niezależne w dużej mierze od woli bohatera wędrówki po mieście, które $\mathrm{w}$ wielu sytuacjach przypomina labirynt. Miasto występuje w utworze jako przeciwnik bohatera, jest animizowane i nabiera cech żywej istoty, świadomie przeciwstawiającej się obcemu elementowi: „город использовал против него не только свою привычную зимнюю маскировку - он злоказненно и кардинально переменился за те годы, что Филиппов старался о нем забыть" (s. 218). W tym kontekście awaria sieci ciepłowniczej oraz spadek temperatury, towarzyszące przyjazdowi bohatera, mogą sygnalizować obronę samego Miasta jako żywego organizmu przed potencjalnym zagrożeniem utożsamianym z Filippowem. Jednocześnie sam bohater jest człowiekiem zagubionym, co ilustruje na przykład scena, w której owinięty w prześcieradło i w mokrej koszuli błąka się po korytarzu, nie mogąc odnaleźć drzwi swojego pokoju. Innym przykładem jest jego skłonność do gubienia czapek, które dostaje od litujących się nad nim ludzi. Motyw gubienia się w mieście oraz utraty okryć głowy związany jest z zagubieniem życiowym reżysera. Fila boi się rozmowy z Pio- 
trem, a także nieuniknionej w tej sytuacji konfrontacji z sobą samym, dlatego też stara się odwlec w czasie to spotkanie.

Zwraca uwagę fakt, że Filippow nie czyni żadnych kroków by kupić sobie ubranie, które chroniłoby go przed zimnem. Celowe wystawianie się na przeraźliwy chłód może być traktowane jako sposób odwrócenia uwagi od wyrzutów sumienia, związanych z poczuciem winy za rozpad małżeństwa. Przemiana bohatera, z jaką mamy do czynienia w utworze, sugeruje z kolei, że cierpienie jest nieodzownym elementem przyszłej transformacji protagonisty, etapem koniecznym do dokonania moralnego wyboru, jaki w finale nastąpi, co przywodzi na myśl koncepcję Fiodora Dostojewskiego o cierpieniu jako drodze do przebaczenia sobie, innym, przeżycia katharsis i odkupienia grzechów ${ }^{21}$. Powodem wyrzutów sumienia bohatera może być uświadomienie sobie zdrady emocjonalnej, jakiej dopuścił się wobec żony (zajęty własnymi artystycznymi pomysłami, ignorował potrzeby uczuciowe Niny) oraz roli, jaką odegrał w jej śmierci. Przywołanie emocji towarzyszących protagoniście przed laty na wieść o odejściu Niny tekstualizuje się we wspomnieniu oddania bezdomnej spotkanej przy śmietniku ubrania żony. Garsonka w stylu Chanel, uszyta Ninie przez matkę Filippowa, wyróżniała młodą dziewczynę spośród jednakowo ubranego w tamtych latach tłumu, a jednocześnie symbolizowała obudzoną pod wpływem uczucia kobiecość, po rozstaniu zaś - stała się substytutem Niny, na którym bohater wyładowuje negatywne emocje spowodowane urażoną godnością osobistą.

Elementem kluczowym dla transformacji bohatera jest moment, w którym uświadamia sobie, że „прятаться бесполезно” (s. 173), bowiem przyjęcie pasywnej postawy uzależnia jego los od wyborów i działań innych. Podjęcie decyzji o udaniu się do scenografa i przeprowadzeniu z nim męskiej rozmowy prowadzi do pogłębionej refleksji bohatera - pojawiają się myśli o sensie życia, istocie szczęścia i ostatecznie Filippow dokonuje rozrachunku z sobą samym i swoją przeszłością. Istotne znaczenie ma tutaj również wizja, jakiej doznaje - Fila obserwuje utrzymany w stylu groteski spektakl, którego tematem jest jego własne życie. Zderzenie własnych wyobrażeń z odmienną perspektywą ich postrzegania (mężczyzna występuje nie w typowej dla siebie roli reżysera, lecz widza) prowadzi do odkrycia

${ }^{21}$ Szerzej o koncepcji Dostojewskiego patrz: M. Michalska-Suchanek, Poprzez mrok i piekło. Soteriologia prawosławna wedtug Fiodora Dostojewskiego, „Wschodni Rocznik Humanistyczny" 2014, t. 10, s. 307-316, http://wrh.edu.pl/wp-content/ uploads/2018/06/21_Michalska-Suchanek_WRH_10_2014.pdf (3.03.2019). 
przez Filippowa, że jego życie jest płytkie, oparte na grze pozorów i sztucznych, nasyconych teatralnością gestów zachowaniach. Sam bohater cierpi na syndrom melancholiczny - ma poczucie nudy i pustki w swoim życiu, skrywanych pod maską pozornej obojętności wobec ludzi i świata. Powodem takiego stanu rzeczy są nie tylko traumatyczne przeżycia związane $\mathrm{z}$ odejściem, a następnie śmiercią żony, ale też niepowodzenia, jakie go spotkały na początku kariery na Zachodzie, zanim stał się wielbionym przez tłumy reżyserem. To wówczas, by poradzić sobie z napięciem emocjonalnym, Filippow stworzył teorię, zgodnie z którą „лишь пустота способна идеально заполнить человеческую душу. Только она не оставит в душе ни одного незанятого местечка" (s. 126).

Teoria ta łączy się jednocześnie ze stworzeniem przez artystę alternatywnego „Ja”, czyli postaci sobowtóra - Demona Pustki, towarzyszącego mu szczególnie w chwilach samotności i często sarkastycznie komentującego jego poglądy i postawy. Jak zauważa Michał Januszkiewicz, motyw sobowtóra, charakterystyczny dla epoki romantycznej, dotyczy często antybohaterów o cechach demonicznych (Don Juan, Pieczorin, Kordian) i znajduje wyraz w rozdarciu, walce dobrych i złych sił, ironicznym dystansie do świata, manifestując zawsze odosobnienie, samotność i cierpienie indywiduum ${ }^{22}$. Demon Pustki, o którym sam Filippow powie, że jest to jego „опостылевшее alter ego" (s. 213) występuje w roli antagonisty bohatera (podzielając zamiłowanie reżysera do elegancji i sarkazmu w ocenie rzeczywistości, różni się od niego większą prostotą zachowania i szczerością wypowiedzi), przewodnika w wędrówce w głąb siebie (pojawia się zawsze wtedy, gdy Filippow trzeźwieje, a zatem jest zdolny do analizy swoich zachowań), jednocześnie jego obecność to zapowiedź przyszłej śmierci reżysera. W utworze Giełasimowa postać ta odgrywa istotne znaczenie $\mathrm{w}$ podejmowaniu przez artystę refleksji nad sobą, w spoglądaniu na własne życie z dystansu, w konfrontowaniu rzeczywistego „Ja” z wyimaginowanym autowizerunkiem. Na ten aspekt sobowtóra zwraca uwagę Rozalia Słodczyk, pisząc, że sobowtór generuje: „poczucie rozbicia bohatera, jego pytania o własną egzystencję, wątpliwości dotyczące tożsamości i integralności oraz niepewność i niepokój, które mogą prowadzić do szaleństwa lub

\footnotetext{
${ }^{22}$ M. Januszkiewicz, $W$ horyzoncie nowoczesności: antybohater jako pojęcie antropologii literatury, „Teksty Drugie” 2010, nr 3, s. 66, http://rcin.org. pl/Content/49027/WA248_66131_P-I-2524_januszkiew-horyzoncie.pdf (5.03.2019).
} 
śmierci”"23. Demon Pustki - brat-bliźniak protagonisty przeprowadza go przez labirynt miasta, niekiedy ratując przed zagrożeniem, by mogła się dokonać przemiana bohatera, której istotą jest adaptacja do otoczenia, wyrażająca się w akceptacji zasad współżycia reprezentowanych przez mieszkańców rodzinnego miasta (w szerszym znaczeniu - kolektywnych wartości Wschodu) i porzuceniu nieautentycznego, sztucznie wykreowanego, obrazu własnej osoby. Obserwowana w toku rozwoju akcji zmiana stroju protagonisty staje się sygnałem, że traci on status obcego, wtapia się w lokalną społeczność.

W kontekście omawianej w niniejszym tekście problematyki warto zwrócić uwagę na ubiór Demona Pustki - jego rodzaj i kolorystykę. Jerzy Faryno zauważa, że charakterystyka bohaterów za pomocą gamy kolorystycznej może służyć przeciwstawieniu sobie postaci jako wyrazicieli innych kultur, gustów i poglądów, ale również być znakiem zgodności ${ }^{24}$.

Odzież Demona Pustki została zaledwie kilkukrotnie odnotowana w utworze - w scenie uratowania Filippowa przed atakiem złodziei, ubranie sobowtóra (,[...] был одет в огромный тулуп, ушанку из чернобурки и белые армейские валенки”, s. 213) jest niemal identyczne z tym, co ma na sobie bohater („Филя [...] стал обладателем теплой шапки и толстого ватника [...]”, s. 213), w finale utworu zaś, gdy towarzyszy śmierci reżysera, Demon pojawia się w „яркожелтом пуховике” (s. 345). Żółta barwa odzieży Demona Pustki w tak szczególnym momencie decydowania się losu bohatera przywołuje skojarzenia ze słońcem, „które przybywa z daleka, wyłania się z mroków jako posłaniec światła i znów znika w ciemności” 25 i symbolizuje intuicję, wskazującą kierunki wydarzeń. Oś kolorystyczna czerń - biel - złoto (wyrażane kolorem żółtym) służy w symbolice do zamanifestowania duchowego wznoszenia się, a zatem barwa odzieży, w jakiej obserwujemy Demona, będącego przecież sobowtórem bohatera, pozwala widzieć w nim jasną stronę protagonisty, z którą jego ciemna strona ostatecznie się zespala.

Kod odzieżowy jest elementem kształtowania idei utworu w partiach tekstu odnoszących się zarówno do teraźniejszości, jak i do

${ }^{23}$ R. Słodczyk, Poe a motyw sobowtóra w literaturze XIX wieku, „Tekstualia” 2009, nr 1(16), s. 36-37, https://tekstualia.pl/files/d9af879c/slodczyk_rozalia-poe_a_ motyw_sobowtora_w_literaturze_xix_wieku.pdf (5.03.2019).

${ }^{24}$ Е. Фарино, Введение в литературоведение..., s. 326.

${ }^{25}$ Zob. hasło „żółty” w: J. E. Cirlot, Stownik symboli, przeł. I. Kania, Wyd. Znak, Kraków 2000, s. 183. 
przeszłości. Ubranie już wcześniej stanowiło dla bohatera wyzwanie, ściśle splecione z poszukiwaniem własnej tożsamości, czego dowiadujemy się z jego wspomnień. Jedno z nich dotyczy zimowego dnia sprzed 27 lat, kiedy to bohater jako 15-letni chłopak, jak co dzień, szedł do szkoły:

Одеревеневшая на морозе спортивная сумка из дешевого дерматина постоянно сползает с плеча, норовит свалиться, но поправлять ее нелегко, потому что на пятнадцатилетнем Филиппове огромный армейский тулуп, пошитый, или, скорее, построенный в расчете на здоровенного бойца, и щуплый Филиппов едва передвигается в этой конструкции, пиная от скуки ее твердые, как фанера, широченные полы. Родные руки в этом сооружении ощущаются как протезы (s. 36-37).

Groteskowy wygląd bohatera to efekt charakterystycznych dla ostatnich lat istnienia ZSRR braków zaopatrzeniowych. Mieszkańcy Kraju Rad, a szczególnie terenów położonych poza wielkimi metropoliami, skazani byli na mozolne „zdobywanie” przedmiotów codziennego użytku. Kożuch, który ma na sobie Fila, jest przedmiotem dumy ojca, któremu udało się go kupić po znajomości, natomiast dla piętnastolatka to źródło udręki (kożuch jest niewygodny - krępuje ruchy i utrudnia poruszanie się), powód do wstydu i przyczyna osamotnienia i odrzucenia przez środowisko rówieśników (chłopcy wyśmiewają się z wyglądu kolegi, drażnią go i wyzywają, gdy wraca ze szkoły do domu).

Kolejne wspomnienie pochodzi z czasów, gdy bohater miał 25 lat. I tutaj znaczący staje się motyw ubrania:

Он уже вдовец и сам покупает себе одежду. Зимой он больше не похож на бродячий памятник. На нем двое штанов, толстый свитер, крытый черным сукном полушубок, ботинки из оленьих камусов, ондатровая шапка и огромные цигейковые рукавицы. [...] Зимой так одето все мужское население города, и каждый абсолютно доволен тем, что он не хуже всех остальных (s. 38-39).

Stanowiące część zimowego pejzażu miasta kożuchy i półkożuszki unifikowały społeczeństwo, pozbawiając ludzi indywidualności, co było zgodne z ideologicznymi założeniami komunizmu. Niemożność zamanifestowania swojej osobowości poprzez strój i wykraczające ponad przeciętność zachowanie wzmagało w jednostkach twórczych poczucie życiowej stagnacji i braku perspektyw, próba zmiany kończyła się niepowodzeniem z powodu trudności w realizacji własnych 
dążeń. To z kolei sprawiało, że rzeczywistość postrzegana była jako szara i martwa, co w omawianym utworze wyrażane jest za pomocą metafory zamarzania, chłodu ogarniającego wszystko i wszystkich. Szansą na wyjście z tego egzystencjalnego impasu okazała się Gorbaczowowska pieriestrojka charakteryzowana w utworze również z perspektywy zmiany codziennego wyglądu obywateli. Otwarcie granic sprowadziło do Rosji przedstawicieli różnych wspólnot wyznaniowych, którzy stali się w owych czasach pierwszymi kreatorami mody:

Миссионеры приезжали в ярких импортных пуховиках, и, очевидно, именно в этом состояла их настоящая миссия. [...] для молодого Филиппова эти фирменные сияющие ризы оказались подлинным и практически религиозным откровением. В двадцать пять лет он экстатически в о з меч тал о красной куртке на гагачьем пуху, и ничто в целом мире уже не в силах было остановить его на этом высоком пути. Так в его жизни наступил конец эпохи всеобщего черного сукна (rozstrzelenie moje - L.K.). Разрыв с родным городом стал неизбежен (s. 39-40).

Badacze kultury podkreślają, że moda wyrażać może niezgodę na otaczającą rzeczywistość, a będąca jej cechą immanentną zmienność sygnalizuje często konflikt starego i nowego porządku pociągającego innych atrakcyjnością bazującą na zaproponowaniu czegoś nowego, często szokującego i ekstrawaganckiego ${ }^{26}$. Fascynacja bohatera zachodnim stylem ubierania się, dająca okazję do wyrażenia własnej osobowości poprzez barwę, fakturę i jakość materiału, ujawnia nieprzystawalność do świata, w jakim przyszło mu żyć, za którą może kryć się (choć nie jest to wyrażone explicite) negatywna ocena systemu polityczno-społecznego. Przypomnijmy, że dbałość o nienaganny strój, mająca odzwierciedlać przeciwstawienie się uniformizacji czasów komunizmu (a zatem i pośrednia jego ocena), cechowała także Fandorina. Brudne, szare ulice, po których przemieszczają się jednakowo ubrani mieszkańcy, będący produktem unifikującego społeczeństwo komunizmu, zaczynają odtąd być kojarzone przez Filippowa z przestrzenią peryferyjną, Europa Zachodnia staje się zaś centrum wartości i możliwości, do jakich bohater zamierza dążyć. Znajduje to również odzwierciedlenie w symbolice kolorów - zimnej regresywnej czerni, kojarzącej się z procesami odrzucenia, bierności

${ }^{26}$ M. Hendrykowski, Semiotyka mody, „Kultura Współczesna” 2013, nr 4, s. 227228, https://www.nck.pl/upload/archiwum_kw_files/artykuly/24._marek_hendrykowski_-_semiotyka_mody.pdf (7.03.2019). 
i osłabienia, przeciwstawiona zostaje ciepła i progresywna czerwień, utożsamiana z aktywnością i intensywnością ${ }^{27}$.

Z czasem okazuje się jednak, że Zachód nie sprostał oczekiwaniom Filippowa. Konieczność dostosowania się do nowych warunków i norm spowodowała pogłębienie duchowej pustki bohatera, co stało się szczególnie odczuwalne w rodzinnym mieście z perspektywy dziesięciu lat. Uświadomienie przez reżysera fałszywości dotychczasowej egzystencji rodzi w nim potrzebę odpokutowania za swoje winy i oczyszczenia duszy, czego świadectwem jest próba uratowania od zamarznięcia dwóch psów oraz poszukiwania zaginionego dziecka ${ }^{28}$, a także przekazanie oszczędności lekarce Annie Rudolfownej, której bliscy zamarzli w zepsutym samochodzie. Dokonując tych bohaterskich jak mu się wydaje czynów, Filippow dostrzega, że wstępuje $\mathrm{w}$ niego nadzieja i siła. $\mathrm{W}$ istocie nie tyle pomaga on innym, ile ratuje w ten sposób siebie, a właściwie te resztki człowieczeństwa, które zostały skrzętnie ukryte pod gadżetowym wizerunkiem. Nieodłącznym elementem tych przeobrażeń jest stopniowa zmiana stylu ubierania się, co świadczy o dokonującym się w nim przewartościowaniu kosztowna i ekstrawagancka odzież maskowała ubóstwo duchowo-moralne Filippowa, odzież praktyczna zapowiada duchową odnowę bohatera. Podobnie jak zrzucenie koszuli przez bohatera powieści Griszkowca, pozbycie się zachodniej odzieży przez Filę, oznacza odnalezienie siebie, pogodzenie z sobą samym. Protagonista stopniowo wyzwala się spod presji bycia modnym, adaptując się do warunków panujących $\mathrm{w}$ mieście, akceptując własną w nim rolę i rezygnując z roszczeniowej postawy względem innych. Filippow nabiera poczucia sensu życia („Он чувствовал, как сила возвращается к нему, и понимал, что все идет как надо, самым наилучшим образом", s. 201) i co przekłada się na wygląd bohatera („Одет он был уже во все местное. В кладовках Данилова нашелся и новенький пуховик, и унты по размеру, и теплые вторые штаны”, s. 263). Dokonująca się transformacja protagonisty odsyła nas do koncepcji piękna, dobra i prawdy, zaproponowanej przez Dostojewskiego. Dla autora Idioty (Идиom, 1869) piękno, podobnie jak natura ludzka, ma charakter antynomiczny, jak pisze jeden z badaczy, „przybiera postać maski, za którą człowiek ukrywa swoje prawdziwe oblicze [...] człowiek może

${ }^{27}$ Zob. hasło „kolor” w J. E. Cirlot, Stownik..., s. 182.

${ }^{28}$ Zachowania te można rozpatrywać jako metafory ratowania przez bohatera samego siebie z przeszłości oraz próbę, jaką musi przejść zanim w finale utworu uratuje życie nastolatka. 
być postrzegany jako istota wrażliwa na piękno, i równocześnie może pozostać całkowicie obojętny na dobro, prawdę i piękno" ${ }^{29}$. Dlatego też Giełasimow przeprowadza swojego bohatera (artystę, a zatem człowieka wrażliwego na piękno, a jednocześnie egocentryka) przez kolejne doświadczenia, które skutkują ostatecznie odrzuceniem fałszu i egoizmu (symboliczne rozstanie z powierzchowną formą, jaką była kurtka od Burberry) i zastąpieniem ich gestami i czynami szlachetnymi. Apogeum ewolucji bohatera staje się finał utworu, kiedy to Fila oddaje swoją kurtkę dziewiętnastoletniemu rannemu kierowcy i otrzymuje szansę (niestety, tylko w wyobraźni) naprawienia błędu z przeszłości poprzez powtórne podjęcie tym razem właściwej, decyzji o odsunięciu zasłony pieca i uratowaniu Niny. Zdaniem autora powieści gest ten ma symbolizować wyzwolenie bohatera, uwolnienie od wykreowanego przez niego samego sztucznego świata, w którym odrzucane jest życie jako takie ${ }^{30}$. Rezygnacja z życia, utożsamiana $\mathrm{z}$ brakiem zaangażowania w kardynalne sprawy ludzkiej egzystencji za cenę zastępowania go symulakrami prowadzi bowiem, jak sugeruje fabuła utworu, do dystrofii duchowej, do degradacji jednostki. I choć, jak się wydaje na przykładzie Eduarda Filippowa, przezwyciężenie stanu wewnętrznej hibernacji jest możliwe, w przypadku bohatera wyczyn ten okazał się jego ostatnim aktem wolnej woli, po którym nastąpiła śmierć.

Jak można zauważyć, motyw ubrania, podkreślający wymowę ideową utworu, wyznaczał drogę dojrzewania głównego bohatera, przebiegającą od negacji uniformów czasów komunistycznych poprzez fascynację tekstyliami zachodnich projektantów, spełniającymi role kostiumów czy też maski, jeśli weźmiemy pod uwagę teatralność zachowań bohatera, po akceptację i wybór funkcjonalnej odzieży dostosowanej do okoliczności. Wyzwania, przed jakimi rzeczywistość postawiła Filippowa, zmuszając go do skonfrontowania się z własnymi lękami i demonami, wykazały, że jego dotychczasowe - medialne - życie jest puste i prowadzi do otchłani, czemu zapobiec może jedynie altruistyczny gest, wymagający pozbycia się fałszywego „ja” (manifestowanego luksusową odzieżą) i odnalezienia w sobie człowieczeństwa.

${ }^{29}$ Ks. A. Penke, Piękno stowa wcielonego u Fiodora Dostojewskiego, „Studia Gdańskie" 2007, nr XXI, s. 103-104.

${ }^{30}$ М. Кучерская, Лауреат премии „Нацбест” Андрей Геласимов написал роман-притчу „Холод”, „Ведомости”, 13.01.2015, https://www.vedomosti.ru/ lifestyle/articles/2015/01/13/vymerzanie-cheloveka (7.03.2019). 


\section{REFERENCES}

Akhmadishina, Farida. "Problema samoidentifikatsii v romane Ye. Grishkovtsa 'Rubashka.." 28 February 2019. <https://moluch.ru/conf/phil/archive/108/5793/> [Ахмадишина, Фарида. "Проблема самоидентификации в романе Е. Гришковца ‘Рубашка'.” 28.02.2019.

$<$ https://moluch.ru/conf/phil/archive/108/5793/>].

Bykov, Dmitriy. "Andrey Gelasimov pokhozh na pisatelya." 28 February 2019. <http://www.zh-zal.ru/novyi_mi/2003/1/bykov.htяml> [Быков, Дмитрий. “Андрей Геласимов похож на писателя." 28.02.2019. <http://www.zh-zal.ru/ novyi_mi/2003/1/bykov.html>].

Charko-Klekot, Paulina. "Szaleństwo codzienności we współczesnej dramaturgii rosyjskiej.” 28.02.2019. <https://www.depot.ceon.pl/bitstream/handle/ 123456789/14136/o6.\%20Charko-Klekot\%20Szale\%C5\%84stwo\%2ocodzien-

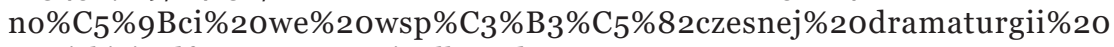
rosyjskiej.pdf?sequence $=1$ \&isAllowed $=\mathrm{y}>$.

Cirlot, Juan Edwardo. Stownik symboli. Transl. I. Kania. Kraków: Znak, 2000.

Farino, Yezhi. Vvedeniye $v$ literaturovedeniye. Sankt-Peterburg: RGPU im. A. I. Gertsena, 2004. [Фарино, Ежи. Введение в литературоведение. СанктПетербург: РГПУ им. А. И. Герцена, 2004].

Gelasimov, Andrey. Kholod: roman $v$ trekh deystviyakh s antraktami. Moskva: Eksmo, 2015. [Геласимов, Андрей. Холод: роман в трех действиях с антрактами. Москва: Эксмо, 2015].

Giddens, Anthony. Nowoczesność i tożsamość. „Ja” i społeczeństwo w epoce późnej nowoczesności. Transl. A. Szulżycka. Warszawa: PWN, 2001.

Hendrykowski, Marek. "Semiotyka mody." 7.03.2019. <https://www.nck.pl/upload/archiwum_kw_files/artykuly/24._marek_hendrykowski_-_semiotyka_ mody.pdf $>$.

Januszkiewicz, Michał. "W horyzoncie nowoczesności: antybohater jako pojęcie antropologii literatury.” 5.03.2019. <http://rcin.org.pl/Content/49027/WA248_66131_P-I-2524_januszkiew-horyzoncie.pdf $>$.

Kalmykov, Vyacheslav. "50 samykh yarkikh debyutov v proze nachala tret'yego tysyacheletiya.” 28 February 2019. <http://web.archive.org/web/20130920233835/ http://litrossia.ru/archive/140/reit/3457.php> [Калмыков, Вячеслав. "50 самых ярких дебютов в прозе начала третьего тысячелетия.” 28.02.2019. <http://web.archive.org/web/20130920233835/http://litrossia.ru/archive/140/reit/3457.php>].

Kozicka, Danuta. "Podróżny horyzont rozumienia.” Teksty Drugie 2006, no. 1-2. $270-285$.

Kucherskaya, Maya. "Laureat premii 'Natsbest' Andrey Gelasimov napisal roman 'Kholod'." 7 March 2019. <https://www.vedomosti.ru/lifestyle/articles/2015/o1/13/vymerzanie-cheloveka> [Кучерская, Майя. “Лауреат премии 'Нацбест' Андрей Геласимов написал роман-притчу 'Холод'.” 7.03.2019. <https://www.vedomosti.ru/lifestyle/articles/2015/01/13/vymerzanie-chelove$\mathrm{ka}>$ ].

Lazaresku, Ol'ga. "Predmetnyy motiv odezhdy v russkoy literature i fol'klore." 28 February 2019. <https://cyberleninka.ru/article/n/predmetnyy-motivodezhdy-v-russkoy-literature-i-folklore> [Лазареску, Ольга. "Предметный мотив одежды в русской литературе и фольклоре.” 28.02.2019. <https:// 
cyberleninka.ru/article/n/predmetnyy-motiv-odezhdy-v-russkoy-literature-ifolklore $>$.

Łotman, Jurij. Rosja i znaki. Kultura szlachecka w wieku XVIII i na poczqtku XIX. Transl. B. Żyłko. Gdańsk: słowo/obraz terytoria, 2010.

Michalska-Suchanek, Mirosława. "Poprzez mrok i piekło. Soteriologia prawosławna według Fiodora Dostojewskiego." 3.03.2019. <http://wrh.edu.pl/wp-content/ uploads/2018/o6/21_Michalska-Suchanek_WRH_10_2014.pdf >.

Penke, Andrzej. “Piękno słowa wcielonego u Fiodora Dostojewskiego.” Studia Gdańskie 2007, no XXI. 101-112.

Pietrowicz, Krzysztof. "Nasze gadżety codzienne, albo o płynności symboli statusu." Na pokaz. O konsumeryzmie w kapitalizmie bez kapitału. Ed. Tomasz Szlendak and Krzysztof Pietrowicz. Toruń: Wydawnictwo Uniwersytetu Mikołaja Kopernika, 2004. 67-81.

Prudnikov, Sergey. “Andrey Gelasimov: Kakoy-to kholod v nas vpolzayet...” 3 March 2019. <http://www.vppress.ru/stories/Andrei-Gelasimov-Kakoi-to-kholod-v-nas-vpolzaet-30568> [Прудников, Сергей. "Андрей Геласимов: Какой-то холод в нас вползает....” 3.03.2019. <http://www.vppress.ru/stories/Andrei-Gelasimov-Kakoi-to-kholod-v-nas-vpolzaet-30568>].

Pustovaya, Valeriya. "Dobryy doktor Gelasimov." 28 February 2019. <https:// magazines.gorky.media/novyi_mi/2005/2/dobryj-doktor-gelasimov.html> [Пустовая, Валерия. “Добрый доктор Геласимов.” 28.02.2019. <https://magazines.gorky.media/novyi_mi/2005/2/dobryj-doktor-gelasimov.html>].

Remizova, Mariya. "Zdravstvuy, proza molodaya...." 28 February 2019. <http:// znamlit.ru/publication.php?id=2213> [Ремизова, Мария. “Здравствуй, проза молодая...." 28.02.2019. <http://znamlit.ru/publication.php?id=2213>].

Skotnicka, Anna. "Niezwykłość codzienności w rosyjskiej prozie drugiej połowy XX wieku." Wielkie tematy kultury $w$ literaturach stowiańskich 6. 135-141. Ed. Malej, Izabella. Tarajło-Lipowska, Zofia. Wrocław: Wydawnictwo Uniwersytetu Wrocławskiego, 2004.

Słodczyk, Rozalia. "Poe a motyw sobowtóra w literaturze XIX wieku." 5.03.2019. <https://tekstualia.pl/files/d9af879c/slodczyk_rozalia-poe_a_motyw_sobowtora_w_literaturze_xix_wieku.pdf $>$.

Sulima, Roch. Antropologia codzienności. Kraków: Wydawnictwo Uniwersytetu Jagiellońskiego, 2000.

Supa, Wanda. Ed. W kręgu problemów antropologii literatury. Antropologia codzienności. Białystok: Wydawnictwo Uniwersytetu w Białymstoku, 2013.

Szydłowska, Joanna. "Retoryka rzeczy a proces zadomowienia w przestrzeniach pojałtańskiego Okcydentu." 28.02.2019. <http://www.anthropos.us.edu.pl/anthropos9/texty/szydlowska.htm>.

Yakovleva, Oksana, Ivanova, Oksana. "Kontsept 'gorod Yakutsk" v romane A. Gelasimova 'Kholod'." 3 March 2019. <https://interactive-plus.ru/e-articles/285/Action285-115185.pdf> [Яковлева, Оксана, Иванова, Оксана. "Концепт 'город Якутск”" в романе А. Геласимова 'Холод'.” 3.03.2019. <https://interactiveplus.ru/e-articles/285/Action285-115185.pdf >].

Żak, Elżbieta. Mieszkańcy rosyjskiej świadomości zbiorowej XX i XXI wieku. Bohater kryminałów Aleksandry Marininej i Borysa Akunina. Kraków: Księgarnia Akademicka, 2014. 
Лилана Калита

ПИДЖАК ОT BURBERRY ИЛИ ПУХОВИК? ОДЕЖДА

И ТРАНСФОРМАЦИЯ ГЕРОЯ РОМАНА АНДРЕЯ ГЕЛАСИМОВА ХОЛОД

Резюме

Данная статья посвящена выявлению значения одежды в контексте изменений главного героя - современного артиста. В своем произведении Геласимов изображает человека, потерявшего жизненные ориентиры, и помещает его в экстремальныеусловия, заставляя зановопересмотретьсвоюжизнь. Значимой составляющей трансформации героя является внешнее преображение: он постепенно теряет черты человека Запада и, поэтапно (путем воспоминаний и встреч с давними знакомыми), углубляясь в себя обретает чувство счастья, находит свое истинное „Я”. Эта перемена свидетельствует о том, что герой созревает к подвигу, который в финале романа совершает.

\section{Liliana Kalita}

\section{BURBERRY JACKET OR PADDED JACKET? CLOTHES AND THE HERO'S EVOLUTION IN ANDREY GELASIMOV'S COLD}

\section{Summary}

Andrey Gelasimov - a representative of contemporary Russian prose - chose for the hero of his novel Cold an artist lost in the world of media expectations. Confronted with extreme weather conditions, the hero tries to cope with his own past, which is portrayed through changes in his looks. The text analyses the stages of this transformation, stressing that modifications in the attire - from the western kind, unsuitable for the climatic conditions, to the one typical for local Russian culture reflect the process of the hero's maturation and self-acceptance. 